\title{
RESEARCH OF HEATING RATES INFLUENCE ON LAYER COAL GASIFICATION OF KRASNOGORSKY AND BORODINSKY COAL DEPOSIT
}

\author{
Stanislav Jankovskiy ${ }^{a}$, Dmitrij Luzhkovoj, Kirill Larionov, Anastasiya Matveeva \\ National Research Tomsk Polytechnic University, Lenina Avenue, 30, 634050, Tomsk, Russia
}

\begin{abstract}
Experimental research of heating rate influence on coal samples gasification process of Krasnogorsky and Borodinsky coal deposit ranks A and 2B was done to define optimal heating mode in high intensification of dispersal of inflammable gases conditions. Abundance ratio of carbon monoxide and nitrogen monoxide, water vapor, carbon dioxide at four values of heating rate within the range of 5 to $30 \mathrm{~K} / \mathrm{min}$. with further definition of optimal heating rate of coals was stated.
\end{abstract}

\section{Introduction}

It is known [1-5], that $80 \%$ of coal produced in Russia are used for energy production by direct burning at thermal power stations, $15 \%$ are used in metallurgy and 5\% are used in chemical industry [5-10]. Rational use of natural resources and effective energy consumption are two main requirements of Guideline №2008/1/EC of European Parliament and Council of the European Union 'About complex prevention and pollution control.'

Within the framework of implementation of the Guideline in Russia three directions of effective use of energy were defined:

- low grade coal gasification with further burning of refined gases at thermal power stations:

- production of substitute natural gas used both in industrial, energetic and domestic sector of economy:

- gasification for syngas, hydrogen and other reducing gases production in chemical industry. Rationale in such directions was specified with active discussions in scientific world.

\section{Experimental research}

Research of gas intensification processes at coal pyrolysis in thick layer was done by synchronic thermal analysis method with the use of apparatus Netzsch STA 449 F3 Jupiter и QMS 403 D Aeolos [7].

\footnotetext{
${ }^{\text {a }}$ Corresponding author: jankovsky@tpu.ru
} 
At the preliminary stage of primary fuels gasification research, their element analysis was defined with the help of scanning electron microscope (CЭM) JEOL JCM-6000 [12]. Preparation of research samples was done in accordance with Government Standard 10742-71 and further screenage was done in accordance with Government Standard 3306-88. Dimensions of particles of the research powders made less than $80 \mathrm{mkm}$.

Element composition of primary coal samples is presented in table 1.

Table 1 Chemical composition of primary coal samples

\begin{tabular}{|c|c|c|}
\hline \multirow{2}{*}{ Element } & \multicolumn{2}{|c|}{ Coal rank, mas.\% } \\
\cline { 2 - 3 } & $\begin{array}{c}\text { Brown "Borodinsk" } \\
\text { deposit }\end{array}$ & Antracite "Krasnogorsk" deposit \\
\cline { 2 - 3 } & $2 \mathrm{~b}$ & $\mathrm{~A}$ \\
\hline $\mathrm{O}$ & 14,25 & 4,04 \\
\hline $\mathrm{C}$ & 65,99 & 82,14 \\
\hline $\mathrm{N}$ & 12,55 & 11,26 \\
\hline $\mathrm{Al}$ & 0,84 & 0,51 \\
\hline $\mathrm{Si}$ & 2,72 & 1,36 \\
\hline $\mathrm{Ca}$ & 1,84 & 0,61 \\
\hline $\mathrm{S}$ & 0,16 & 0,08 \\
\hline $\mathrm{Fe}$ & 1,25 & - \\
\hline $\mathrm{K}$ & 0,4 & - \\
\hline
\end{tabular}

The analysis of primary coal samples allowed getting an element composition of source raw material. On the basis of the research results gases output, which needed fixation on mass spectrometer at experiments on intracyclic gasification modeling was predicted [7].

The prepared samples with mass of $20 \mathrm{mg}$ were analyzed with different heating rate 5, 10, 20, 30 $\mathrm{K} / \mathrm{min}$. Sample air blowing was done with argon consumption of $10 \mathrm{ml} / \mathrm{min}$. and air $-50 \mathrm{ml} / \mathrm{min}$. Maximum temperature of heating composition was $1573 \mathrm{~K}$.

\section{Results and discussion}

As a result of completed series of experiments dependences of fixed mass change of obtained gases on time were received. Relative area is equal to area ratio, defined by integral summing up, to mass of weighed portion of coal except ash residual.

The results of research are presented in figure 1-4.

Relative area of gases discharge in the figure is $\mathrm{A}$, heating rate is $\mathrm{B}$. 


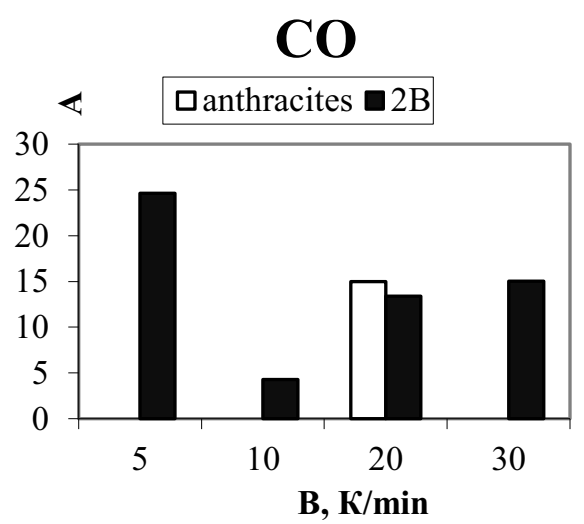

a)

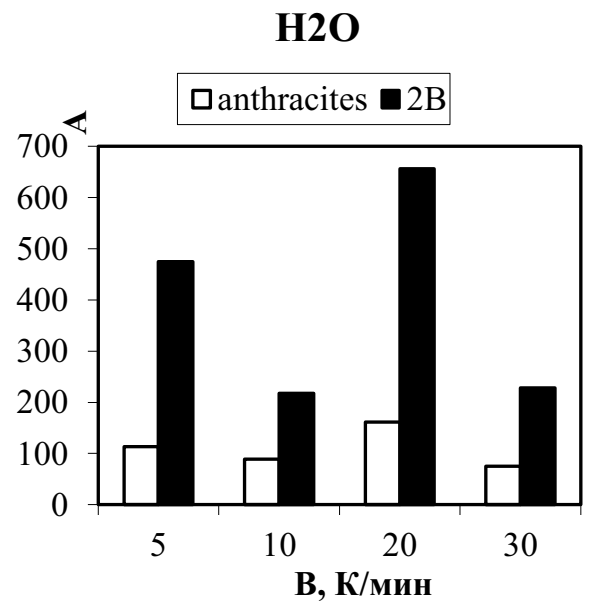

c)

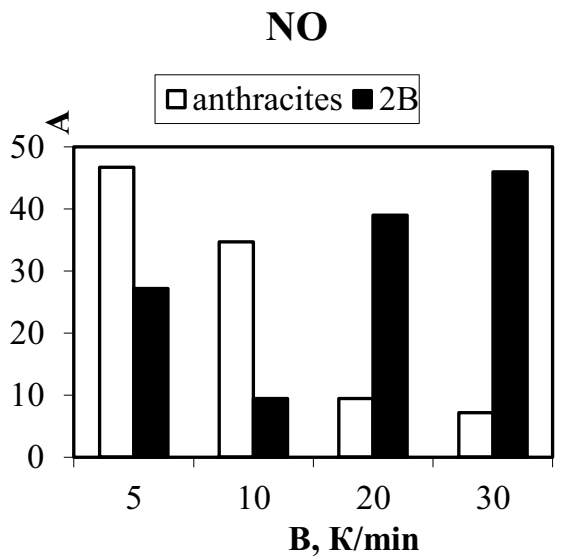

b)

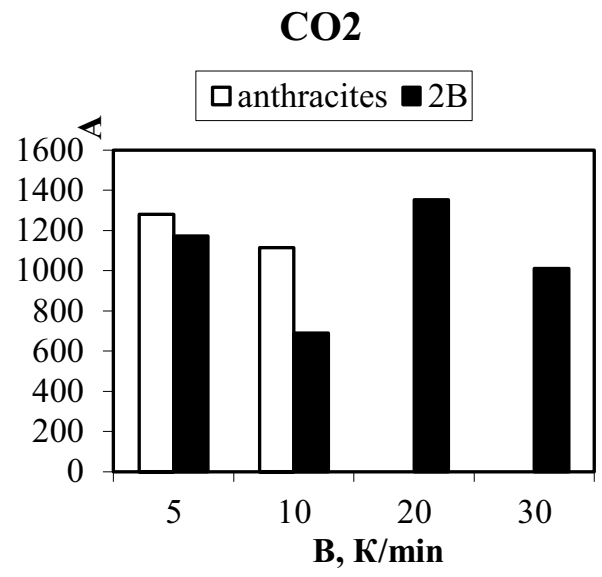

d)

Figure 1. Gas discharge at heating rate of antracite coal rank and brown coal rank 2B, a) carbon monoxide, b) nitrogen monoxide, c) water vapor, d) carbon dioxide.

Analysis of the results presented in figure 1-4 showed that burning gas CO received at low heating rates has the highest discharge intensification. Burning gas output at coal gasification of Krasnogorsk deposit was expressed most of all in the range of heating rate $30 \mathrm{~K} / \mathrm{min}$. In other heating ranges gas discharge was absent or not clearly expressed. Discharged water vapor can be observed at all rate ranges of the research, discharge at heating rates 5 and $30 \mathrm{~K} / \mathrm{min}$. occurs more intensively, transformation of this gas allows getting hydrogen.

There is burning gases decrease from $5 \%$ to $40 \%$ at low heating rates. These data can be explained by the fact that thermal destruction process is accompanied with a big amount of serial/parallel reactions.

\section{Conclusion}

As a result of the research on intracycle gasification modeling of primary coal samples the composition of gases was defined $(\mathrm{CO}, 16 \mathrm{NO}, \mathrm{H} 2 \mathrm{O}, \mathrm{CO} 2)$. The most optimal mode of coal heating 
rate $30 \mathrm{~K} / \mathrm{min}$. was stated which was determined by maximum burning gases discharge applicable for further use at thermal power stations.

The work has been done in FCAEI HE "National Research Tomsk Polytechnic University" in framework of federal focused program implementation "Research and Development on Priority Orientation of Science and Technology Complex Development in Russia for 2014-2020”, unique identifier 'Applied Research and Experimental Developments' RFMEFI58114X0001.

\section{References}

1. Ju. Gavrilov, N. Koroleva, S. Sinicyn, Recycling of solid natural energy (Moskva, RHTU im. D.I. Mendeleeva, 2001). [in Russia]

2. B.Vorob'ev, Ugol' ili gaz - Alternative Energy XXI Century (Moskva, Vestnik Rossijskoj akademii nauk, 2011). [in Russia]

3. V. Gavrilov. Status of the resource base of oil production in Russia and prospects of its capacity (Moskva, Geologija nefti i gaza, 2012). [in Russia]

4. D. Roberts, E.Hodge, D.Harris, J. Stubington, Energy Fuels, 24, 5300 (2010).

5. S. Kim, C. Park, J. Park, S. Lee, J. Rhu, M.Han, S. Yoon, Y.Rhee, Journal of Industrial and Engineering Chemistry, 20, 356 (2014).

6. V. Gremjachkin, E. Mazachenko. Chem. Phys., 12, 18 (2010). [in Russia]

7. I. Glushhenko. Thermal analysis of solid fuels (Moskva, Metallurgija, 1968). [in Russia]

8. K. Larionov, I. Korjashov, S. Jankovskij, V. Gubin, A. Matveev, Studying the composition of the synthesis gas produced by gasification electrophysical situ at the heating rate of different coals, FGAOU VO «Nacional'nyj issledovatel'skij Tomskij politehnicheskij universitet», (2014). [in Russia]

9. G. Shiling, B. Bonn, U. Kraus, Coal gasification (Moskva, Nedra, 1986). [in Russia]

10. S. Filippov, A. Kejko, Gasification of coal in the energy sector (Moskva, Fond «Jenergija bez granic», 2012). [in Russia]

11. V. Miheev, Roentgenometric determinant of minerals (Moskva, Nedra, 1960). [in Russia]

12. Dzh. Goulstejn, Scanning electron microscopy and X-ray microanalysis (Moskva, Mir, 1984). [in Russia] 